\title{
Effect of Sulphur and Selenium on Yield, Selenium Content and Antioxidant Properties in Sunflower (Helianthus annuus L.)
}

\author{
A. Jessie Rebecca*, P. Surendra Babu and M. Chandini Patnaik \\ Department of Soil Science and Agricultural Chemistry, College of Agriculture, PJTSAU, \\ Rajendranagar, Hyderabad - 500 030, India \\ *Corresponding author
}

\section{A B S T R A C T}

\section{Keywords}

DPPH radical scavenging activity, Selenium

content, Sulphur,

Sunflower, Total

flavonoid content, Total

Phenol content, Yield

attributes

Article Info

Accepted:

04 March 2018

Available Online:

10 April 2018
The present investigation was carried out during 2015-16 at Agricultural Research Institute, PJTSAU, Rajendranagar, Hyderabad, Telangana, India. Four levels of soil applied sulphur $\left(0,15,30\right.$ and $\left.45 \mathrm{~kg} \mathrm{~S} \mathrm{ha}^{-1}\right)$ in combination with four levels of foliar sprayed selenium concentration $(0$, 25,50 and $100 \mathrm{ppm}$ ) was tried on sunflower to know their effect on seed yield, selenium content and antioxidant properties. The sunflower crop showed more than $25 \%$ in response to sulphur application. Sunflower seed yield increased with selenium application only up to $50 \mathrm{ppm}$ spray and subsequently, the yield decreased. The selenium content in sunflower seed ranged from 9.12 to $20.12 \mathrm{mg} \mathrm{kg}^{-1}$. The antioxidant properties such as phenols and flavonoids significantly increased with the increased levels of soil applied sulphur and foliar sprayed selenium in sunflower crop.

\section{Introduction}

Selenium (Se) is an important trace element in animal and human nutrition but known as a non-essential element for plants, though its beneficial roles have been reported in the plants capable of accumulating large amount of the element (White et al., 2007). It plays an important role in body antioxidation system. It is considered as an individual antioxidant that can cooperate with other antioxidants such as vitamins $\mathrm{C}$ and $\mathrm{E}$ and in the processes protecting the cells from free radicals. Selenium acts as a cofactor in cellular detoxification of peroxidase. Low Se status in humans may increase the risk of cardiovascular diseases (CVD), cancer and other diseases like Alzheimers, which are caused by free radicals (Fairweather Tait et al., 2011). Selenium participates in thyroid hormone metabolism, immune system, inhibits virulence and slows down the development of AIDS through reducing the speed of HIV development. In India, sunflower is an important oilseed crop. It occupies fourth place among oilseed crops in terms of acreage and production in India (Krishi Jagran, 2015). It is grown in an area of $0.73 \mathrm{~m}$ ha and has 
production of 0.52 million tonnes in India. Sunflower seeds are one of the incredible sources of health benefiting nutrients, minerals, antioxidants and vitamins and are also rich in selenium containing about $79.3 \mu \mathrm{g}$ in $100 \mathrm{~g}$ and come in top 10 foods containing selenium (USDA National Nutrient Database, 2014).

\section{Materials and Methods}

A pot experiment was conducted in a net house in Agricultural Research Institute, Rajendranagar on Alfisol of Rangareddy district, Telangana state during rabi of 2015 to study the performance of sunflower under different sulphur and selenium treatments. Sixteen treatments were taken with combinations of four levels of soil applied sulphur by ammonium sulphate (made at the beginning of the crop @ 0,15, 30 and $45 \mathrm{~kg} \mathrm{~S}$ $\mathrm{ha}^{-1}$ ) and four levels of foliar sprayed selenium $(0,25,50$ and $100 \mathrm{ppm}$ Se) by sodium selenite given at $30^{\text {th }}$ day of the crop. The net house is geographically situated at an altitude of $531 \mathrm{~m}$ above mean sea level (MSL) on $17^{0} 19.443^{\prime} \mathrm{N}$ latitude and $78^{\circ} 23.956^{\prime} \mathrm{E}$ longitude. It is located in the southern agro-climatic zone of Telangana, India.

\section{Pot experiment}

The experiment was conducted in completely Randomized design with four replications. The initial properties of the soil are given in Table 1. The required quantity of $D R S H-1$ variety seed was taken and sown in pots containing $10 \mathrm{kgs}$ of soil. Each pot was sown with 8 seeds @ 2 seeds for each hill. The RDF for sunflower is 75:90:30 of $\mathrm{N}: \mathrm{P}_{2} \mathrm{O}_{5}: \mathrm{K}_{2} \mathrm{O} \mathrm{kg}$ $\mathrm{ha}^{-1}$. Nitrogen was given in three splits i.e., $50 \%$ at the time of sowing, $25 \%$ at 30 DAS (vegetative stage) and $25 \%$ at 50 DAS. Phosphorus and potassium were given once at the time of sowing in the form of single super phosphate and muriate of potash, respectively.
Nitrogen was supplied as ammonium sulphate and urea. Sulphur was given as basal at the time of sowing using ammonium sulphate for 15,30 and $45 \mathrm{~kg}$ sulphur treatments. Selenium was given as foliar spray at 30 DAS (vegetative stage) in the form of sodium selenite $\left(\mathrm{Na}_{2} \mathrm{SeO}_{3}\right)$ for 25,50 and $100 \mathrm{ppm}$ of selenium. Prophylactic plant protection measures were carried out by employing spray application of saaf (carbendazim + mancozeb) @ $2 \mathrm{~g} / \mathrm{l}$ at vegetative, head forming and flowering stage to control leaf spot disease.

\section{Soil sampling and analysis}

Soil was air-dried at room temperature and was sieved using $2 \mathrm{~mm}$ sieve. Soil $\mathrm{pH}$ was measured using a $\mathrm{pH}$ meter (1:2.5 soil water suspension) and Electrical Conductivity was determined by Conductivity meter - Elico CM 180 (Jackson, 1973). Organic carbon was estimated using Chromic acid wet digestion method (Walkley and Black, 1934). Soil available $\mathrm{N}$ was determined using Alkaline potassium permanganate method (Subbiah and Asija, 1956), while available $\mathrm{P}_{2} \mathrm{O}_{5}$ was determined by Olsen's method using $0.5 \mathrm{M}$ $\mathrm{NaHCO}_{3}(\mathrm{pH}$ 8.5) extraction in ECIL GS 5701 SS colorimeter (Olsen et al.,1954). Soil available $\mathrm{K}_{2} \mathrm{O}$ was determined by Neutral normal ammonium acetate method (Mervin and Peech, 1951). Available Sulphur by Turbedimetric method (Chesnin and Yien, 1950) and Total Selenium was determined by Azure B colorimetric method (Mathew and Narayana, 2006).

\section{Plant sampling and analysis}

The crop was harvested at 90 DAS (head drop stage). The plants were uprooted and harvested separately according to treatments. The heads were separated from the whole plant and kept for shade drying for 3 days. The seeds collected were then oven dried at $65^{\circ} \mathrm{C}$ and was powdered. 


\section{Total selenium estimation}

The method outlined by Levesque and Vendette (1970) was employed for digestion of seed samples for Se determination. The digested samples are then used for determination of total selenium by using Azure B as a chromogenic reagent as outlined by Mathew and Narayana (2006) using spectrophotometer (Model ECIL GS 5701 SS) at $644 \mathrm{~nm}$ wavelength. It is expressed in $\mathrm{mg}$ $\mathrm{kg}^{-1}$.

\section{DPPH Radical Scavenging Activity}

Scavenging of 2,2-Diphenyl-1-picrylhydrazyl (DPPH) was assessed by the method of Koleckar et al., (2007) using ascorbic acid as a standard. Absorbance was measured in spectrophotometer at $517 \mathrm{~nm}$ (Model ECIL GS 5701). It is expressed as percentage.

Total flavonoid content was determined using the aluminium chloride colorimetry (Chang et al., 2002) using quercetin as a standard flavonoid compound in spectrophotometer at $415 \mathrm{~nm}$ (Model ECIL GS 5701). The results are expressed as $\mathrm{mg}$ of quercetin equivalents per gram of the sample.

Total phenolic compounds were determined with Folin-Ciocalteau reagent according to the method of Singleton and Rossi (1965) using chlorogenic acid as a standard phenolic compound The absorbance was measured at $725 \mathrm{~nm}$ using spectrophotometer (Model ECIL GS 5701).

\section{Statistical analysis}

The experimental data was analyzed for statistical significance of different treatments on various characters following standard procedure given by Snedecor and Cochran (1967) using in house built software package at PJTSAU, Rajendranagar, Hyderabad, India.

\section{Results and Discussions}

\section{Seed yield}

\section{Effect of varying levels of sulphur}

It was observed that there was significant difference in seed yield of sunflower due to application of sulphur (Table 2). With the increase in sulphur levels from 0 to $45 \mathrm{~kg} \mathrm{~S}$ $\mathrm{ha}^{-1}$, the seed yield increased from 3.8 to 6.04 g $\operatorname{pot}^{-1}$. The increase in seed yield due to sulphur application was beyond 25 per cent. Similar results were reported by Syed et al., (2006) in sunflower. They have reported that increase in sulphur levels from 0 to $60 \mathrm{~kg} \mathrm{ha}^{-1}$ increased the seed yield from 8.14 to $10.04 \mathrm{q}$ $\mathrm{ha}^{-1}$. Shamima and Imamul (2002) also reported similar results in sunflower crop. They have reported that the seed yield increased from 1.80 to $3.68 \mathrm{t} \mathrm{ha}^{-1}$ with the application of sulphur @ 0 to $60 \mathrm{~kg} \mathrm{ha}^{-1}$.

\section{Effect of varying levels of selenium}

The sunflower seed yield increased from 4.46 to $5.65 \mathrm{~g} \mathrm{pot}^{-1}$ with the increase in selenium levels from 0 to $50 \mathrm{ppm}$ and then it decreased due to $\mathrm{Se}_{100}$ level of foliar spray. Foliar sprays of selenium at 30 DAS enhanced the yield in the crops but were not found to be beneficial at higher levels of foliar spray. Petr Skarpa (2013) has done similar work on sunflower. $\mathrm{He}$ has found that application of Se at $50 \mathrm{~g}$ $\mathrm{ha}^{-1}$, increased the achenes yield by $3.1 \%$ and application of Se at $150 \mathrm{~g} \mathrm{ha}^{-1}$ decreased the yield by $6.8 \%$.

\section{Interaction of S x Se levels}

There was significant difference in seed yield of sunflower crop due to interaction of sulphur and selenium levels. Seed yield was highest in $\mathrm{S}_{45} \times \mathrm{Se}_{50}\left(7.41 \mathrm{~g} \mathrm{pot}^{-1}\right)$ followed by $\mathrm{S}_{45} \times \mathrm{Se}_{25}$ $\left(6.12 \mathrm{~g} \mathrm{pot}^{-1}\right)$ and least in $\mathrm{S}_{0} \times \mathrm{Se}_{0}(3.45 \mathrm{~g}$ pot $^{-1}$ ) treatments, respectively. 
Table.1 Initial characteristics of the soil collected for the experiment

\begin{tabular}{|c|c|c|c|c|c|c|c|}
\hline pH & $\begin{array}{c}\mathrm{EC} \\
\left(\mathrm{dS} \mathrm{m}^{-1}\right)\end{array}$ & $\begin{array}{c}\mathrm{OC} \\
(\%)\end{array}$ & $\begin{array}{c}\mathrm{Av} \cdot \mathbf{N} \\
\left(\mathrm{kg} \mathrm{ha}^{-1}\right)\end{array}$ & $\begin{array}{c}\mathrm{Av} \cdot \mathrm{P}_{2} \mathrm{O}_{5} \\
\left(\mathrm{~kg} \mathrm{ha}^{-1}\right)\end{array}$ & $\begin{array}{c}\mathrm{Av} \cdot \mathbf{K}_{2} \mathrm{O} \\
\left(\mathrm{kg} \mathrm{ha}^{-1}\right)\end{array}$ & $\begin{array}{c}\mathrm{Av} \cdot \mathrm{S}(\mathrm{mg} \\
\left.\mathrm{kg}^{-1}\right)\end{array}$ & $\begin{array}{c}\text { Total Se } \\
\left(\mathrm{mg} \mathrm{kg}^{-1}\right)\end{array}$ \\
\hline 7.75 & 0.29 & 0.66 & 188 & 58 & 286 & 9 & 2.71 \\
\hline
\end{tabular}

Table.2 Effect of sulphur and selenium on yield of sunflower (seed)

\begin{tabular}{|c|c|c|c|c|c|}
\hline Se $(\mathrm{ppm})$ & \multicolumn{5}{|c|}{ Bulb yield $\left(\mathrm{g} \mathrm{pot}^{-1}\right)$} \\
\hline $\mathrm{S}\left(\mathrm{kg} \mathrm{ha}^{-1}\right)$ & $\mathrm{Se}_{0}$ & $\mathrm{Se}_{25}$ & $\mathrm{Se}_{50}$ & $\mathrm{Se}_{100}$ & Mean \\
\hline $\mathrm{S}_{0}$ & 3.45 & 3.70 & 4.23 & 3.82 & 3.80 \\
\hline $\mathrm{S}_{15}$ & 3.98 & 4.46 & 5.23 & 5.32 & 4.75 \\
\hline $\mathrm{S}_{30}$ & 5.05 & 5.42 & 5.74 & 5.83 & 5.51 \\
\hline $\mathrm{S}_{45}$ & 5.35 & 6.12 & 7.41 & 5.30 & 6.04 \\
\hline Mean & 4.46 & 4.93 & 5.65 & 5.07 & \\
\hline Factors & & $\mathrm{S}$ & $\mathrm{Se}$ & $\mathrm{S} \times \mathrm{Se}$ & \\
\hline $\mathrm{SE}(\mathbf{m}) \pm$ & 0.15 & 0.15 & 0.29 & \\
\hline C.D at 5\% & & 0.43 & 0.43 & 0.86 & \\
\hline
\end{tabular}

Table.3 Effect of sulphur and selenium on selenium content of sunflower seed

\begin{tabular}{|c|c|c|c|c|c|}
\hline Se $(\mathrm{ppm})$ & \multicolumn{5}{|c|}{ Selenium Content $\left(\mu \mathrm{gg}^{-1}\right)$} \\
\hline $\mathrm{S}\left(\mathrm{kg} \mathrm{ha}^{-1}\right)$ & $\mathrm{Se}_{0}$ & $\mathrm{Se}_{0}$ & $\mathrm{Se}_{0}$ & $\mathrm{Se}_{0}$ & $\mathrm{Se}_{0}$ \\
\hline $\mathbf{S}_{0}$ & 10.45 & 15.42 & 17.64 & 20.12 & 15.91 \\
\hline $\mathrm{S}_{15}$ & 10.06 & 14.58 & 16.34 & 18.76 & 14.93 \\
\hline $\mathrm{S}_{30}$ & 9.58 & 13.62 & 15.21 & 17.11 & 13.88 \\
\hline $\mathrm{S}_{45}$ & 9.12 & 12.27 & 14.30 & 15.84 & 12.88 \\
\hline Mean & 9.80 & 13.97 & 15.87 & 17.96 & \\
\hline Factors & & $\mathrm{S}$ & $\mathrm{Se}$ & $\mathrm{S} \times \mathrm{Se}$ & \\
\hline SE(m) & & 0.32 & 0.32 & 0.64 & \\
\hline C.D at 5\% & & 0.94 & 0.94 & 1.88 & \\
\hline
\end{tabular}

Table.4 Effect of sulphur and selenium on DPPH activity of sunflower seed

\begin{tabular}{|c|c|c|c|c|c|}
\hline Se $(\mathrm{ppm})$ & \multicolumn{5}{|c|}{ DPPH (\% inhibition) in sunflower seed } \\
\hline $\mathrm{S}\left(\mathrm{kg} \mathrm{ha}^{-1}\right)$ & $\mathrm{Se}_{0}$ & $\mathrm{Se}_{0}$ & $\mathrm{Se}_{0}$ & $\mathrm{Se}_{0}$ & $\mathrm{Se}_{0}$ \\
\hline $\mathrm{S}_{0}$ & 53.9 & 55.8 & 58.2 & 61.3 & 57.3 \\
\hline $\mathrm{S}_{15}$ & 52.8 & 53.6 & 56.1 & 59.1 & 55.4 \\
\hline $\mathrm{S}_{30}$ & 55.5 & 57.3 & 58.4 & 61.5 & 58.2 \\
\hline $\mathrm{S}_{45}$ & 57.3 & 57.5 & 58.7 & 61.7 & 58.8 \\
\hline Mean & 54.8 & 56.1 & 57.8 & 60.9 & \\
\hline Factors & & $\mathrm{S}$ & $\mathrm{Se}$ & $\mathrm{S} \times \mathrm{Se}$ & \\
\hline $\mathrm{SE}(\mathbf{m}) \pm$ & 1.45 & 1.45 & 2.89 & \\
\hline C.D at 5\% & & $\mathrm{NS}$ & 4.1 & $\mathrm{NS}$ & \\
\hline
\end{tabular}


Table.5 Effect of sulphur and selenium on total flavonoid content of sunflower seed

\begin{tabular}{|c|c|c|c|c|c|}
\hline Se (ppm) & \multicolumn{5}{|c|}{ TFC (mg quercetin/100 g) in sunflower seed } \\
\hline S $\left(\mathrm{kg} \mathrm{ha}^{-1}\right)$ & $\mathrm{Se}_{0}$ & $\mathrm{Se}_{0}$ & $\mathrm{Se}_{0}$ & $\mathrm{Se}_{0}$ & $\mathrm{Se}_{0}$ \\
\hline $\mathbf{S}_{0}$ & 160 & 162 & 169 & 176 & 167 \\
\hline $\mathrm{S}_{15}$ & 153 & 159 & 165 & 169 & 162 \\
\hline $\mathrm{S}_{30}$ & 153 & 154 & 156 & 161 & 156 \\
\hline $\mathbf{S}_{45}$ & 147 & 150 & 151 & 154 & 150 \\
\hline Mean & 153 & 156 & 160 & 165 & \\
\hline Factors & & $\mathrm{S}$ & $\mathrm{Se}$ & $\mathrm{S} \times \mathrm{Se}$ & \\
\hline SE(m) & & 4.5 & 4.5 & 9.00 & \\
\hline C.D at 5\% & & 13.5 & 13.5 & $\mathrm{NS}$ & \\
\hline
\end{tabular}

Table.6 Effect of sulphur and selenium on total phenol content in sunflower seed

\begin{tabular}{|c|c|c|c|c|c|}
\hline Se (ppm) & \multicolumn{5}{|c|}{ TPC (mg gallic acid/100 g FW) in sunflower seed } \\
\hline S $\left(\mathrm{kg} \mathrm{ha}^{-1}\right)$ & $\mathrm{Se}_{0}$ & $\mathrm{Se}_{0}$ & $\mathrm{Se}_{0}$ & $\mathrm{Se}_{0}$ & $\mathrm{Se}_{0}$ \\
\hline $\mathrm{S}_{\mathbf{0}}$ & 905 & 927 & 946 & 972 & 937 \\
\hline $\mathrm{S}_{\mathbf{1 5}}$ & 936 & 953 & 991 & 1017 & 974 \\
\hline $\mathrm{S}_{\mathbf{3 0}}$ & 1005 & 1027 & 1049 & 1083 & 1041 \\
\hline $\mathbf{S}_{\mathbf{4 5}}$ & 1020 & 1046 & 1061 & 1103 & 1058 \\
\hline Mean & 967 & 988 & 1012 & 1044 & \\
\hline Factors & & $\mathrm{S}$ & $\mathrm{Se}$ & $\mathrm{S} \times \mathrm{Se}$ & \\
\hline $\mathrm{SE}(\mathbf{m}) \pm$ & & 28 & 28 & 56 & \\
\hline C.D at 5\% & & 84 & 84 & 165 & \\
\hline
\end{tabular}

The seed yield in $\mathrm{S}_{45} \times \mathrm{Se}_{50}$ is $17.4 \%$ higher when compared to $\mathrm{S}_{45} \times \mathrm{Se}_{25}$ treatment. In the interaction effect, it was found that with the increase in sulphur levels, yield also increased and with the increase in selenium levels, the yield increased till $\mathrm{Se}_{50}$ then decreased.

\section{Selenium content in sunflower seed}

The selenium content in sunflower seeds (Table 3) significantly increased with increased concentrations of foliar sprays of selenium given to crop at $30^{\text {th }}$ day after sowing. It reached to the highest concentration of $17.96 \mu \mathrm{g} \mathrm{g}^{-1}$ due to $100 \mathrm{ppm}$ foliar spray of selenium. However, the Se content in seeds decreased due to increased levels of soil application of sulphur. Lowest selenium content $\left(12.88 \mu \mathrm{g} \mathrm{g}^{-1}\right)$ was noticed when sulphur was applied at $45 \mathrm{~kg} \mathrm{Sha}^{-1}$. The interaction effect of foliar sprayed selenium and soil applied sulphur on selenium content in sunflower seeds was more pronounced due to combination of $\mathrm{Se}_{100}$ and $\mathrm{S}_{45}$ treatment.

DPPH radical scavenging activity in sunflower seed

The data presented in the Table 4 indicated that the DPPH radical scavenging activity (\% inhibition) increased significantly in sunflower seed due to increased concentrations of foliar spray of selenium given at 30 days after sowing. The highest $\%$ inhibition of $60.9 \%$ in sunflower seeds was recorded when selenium was sprayed @ 100 
ppm. The DPPH content also increased with increasing sulphur levels but the change in DPPH content in sunflower seeds due to sulphur application as basal dosage to the soil was non-significant. The DPPH content at any given level of soil applied sulphur was highest at highest rate of foliar sprayed selenium concentration $\left(\mathrm{Se}_{100}\right)$. The interaction was more pronounced at both higher levels of selenium and sulphur (61.7\% inhibition) in sunflower seeds. Increased DPPH \% inhibition with enhanced sulphur application in onion was also reported by Judita et al., (2014).

\section{Total flavonoid contents in sunflower seeds}

The data presented in Table 5 indicated that total flavonoid content increased with increasing selenium concentrations ( 0 to 100 ppm) as foliar spray in sunflower seeds from 153 to $165 \mathrm{mg}$ quercetin/ $100 \mathrm{~g}$. This change in TFC of sunflower seeds due to foliar sprayed selenium was found to be statistically non-significant. The total flavonoid content decreased due to soil application of sulphur and significant decrease was recorded at $\mathrm{S}_{30}$ and $\mathrm{S}_{45}$ levels compared to control. The interaction was more pronounced on TFC at lowest level of sulphur $\left(\mathrm{S}_{0}\right)$ and highest level of selenium $\left(\mathrm{Se}_{100}\right)$ with $176 \mathrm{mg}$ quercetin/100 g D.W of sunflower seed. Poldma et al., (2013), Reilly et al., (2014) and Judita et al., (2015) reported increase in value of quercetin with the increase of selenium application.

\section{Total phenol content of sunflower seeds}

The total phenol content was highest (1044 mg gallic acid/100 g F.W) due to highest selenium spray concentration $(100 \mathrm{ppm})$ and lowest (967 mg gallic acid/100 g) in control. This increase in TPC in sunflower seeds due to enhanced selenium concentration in sprays was statistically non-significant. TPC increased significantly with increase in sulphur application of 30 and $45 \mathrm{~kg} \mathrm{~S}^{-1}$ to the crop (Table 6). The combination of highest level of selenium $\left(\mathrm{Se}_{100}\right)$ and highest level of sulphur $\left(\mathrm{S}_{45}\right)$ had pronounced effect on total phenol content in sunflower seed (1103 mg gallic acid/100 g D.W). Reilly et al., 2014 reported increased supplementation of selenium increases total phenol content of onion.

\section{References}

Chang, C.C., Yang, M.Y., Wen, H.M and Chern, J.C. 2002. Estimation of total flavonoids content in propolis by two complementary colorimetric methods. Journal of Food and Drug Analysis. 10: 178-182.

Chesnin, L and Yien, C.H. 1950. Turbidimetric determination of available sulphate. Soil Science Society of America Proceedings. 15: 149-151.

Fairweather Tait, S.J., Bao, Y., Broadley, M.R., Collings, R., Ford, D., Hesketh, J.E and Hurst, R. 2011. Selenium in human health and disease. Antioxidants and Redox Signaling. 14: 1337-1383.

Jackson, M. L. 1973. Soil Chemical Analysis. Prentice Hall of India Private Limited. New Delhi. Physiology. 10 (4): 400-403.

Judita Bystricka, Janette Musilova, Petra Kavalcova, Beata Volnova. 2014. The influence of sulphur on the content of total polyphenols and antioxidant activity in onion (Allium cepa L.). Journal of Microbiology, Biotechnology and Food Sciences. 3(3): 199-201.

Judita Bystricka, Petra Kavalcova, Janette Musilova, Jan Tomas, Tomas Toth and Matyas Orsak. 2015. Selenium and its influence on the content of polyphenol compounds in onion (Allium cepaL.). Journal of Microbiology, Biotechnology and Food Sciences. 4: 23-26.

Koleckar, V., Jun, D., Opletal, L., Jahodar, L and Kuca, L. 2007. Assay of radical scavenging activity of antidotes against 
chemical warfare by DPPH test using sequential injection technique. Journal of Applied Biomedicine. 5: 81-84.

Krishi Jagran. 2015. All India Area, production and yield status of major crops during 2012-13 \& 2011-12. Krishi Jagran website.

Levesque, $\mathrm{M}$ and Vendette, E. D. 1970. Selenium determination in soil and plant materials. Canadian Journal of Soil Science. 341:85-93.

Mathew Mendalin and Narayana Badiadka. 2006. An easy spectrophotometric determination of selenium using azure B as a chromogenic reagent. Indian Journal of Chemical Technology. 13: 455-458.

Mervin, H.D and Peech, M. 1951. Exchangeability of soil potassium in the sand, silt and clay fractions as influenced by the nature of the complementary exchangeable cation. Proceedings Soil Science Society of America. 15:125.

Olsen, S. R., Cole, C. V., Watanbe, F. S and Dean, L. A. 1954. Estimation of available phosphorus in soils by extraction with sodium bicarbonate. United States Department of Agriculture, Circular No. 939.

Petr Skarpa. 2013. Fortification of sunflower plants (Helianthus annuusL.) with selenium. Journal of Microbiology, Biotechnology and Food Sciences. 2(1): 1569-1579.

Poldma Priit, Ulvi Moor, Tonu Tonutare, Koit Herodes and Riin Rebane. 2013. Selenium treatment under field conditions affects mineral nutrition, yield and antioxidant properties of bulb onion (Allium cepa L.). Acta Scientiarum
Polonorum., HortorumCultus. 12(6): 167181.

Reilly, K., Valverde, J., Finn, L., Gaffney, M., Rai, D.K and Brunton, N. 2014. A note on the effectiveness of selenium supplementation of Irish-grown Allium crops. Irish J Agric Food Res. 53:91-99.

Shamima Nasreen and Imamul Huq, S.M. 2002. Effect of sulphur fertilizer on yield and nutrient uptake of sunflower crop in albaquept soil. Pakistan Journal of Biological Sciences. 5(5): 533-536.

Singleton, V.L and Rossi, J.A. 1965. Colorimetry of total phenolics with phosphomolybdic-phosphotungstic acid reagents. American Journal of Enology and Viticulture. 16(3): 144-158.

Snedecor, G.W and Cochran, W.G. 1967. Statistical methods. Oxford and IBH publishing company. New Delhi. 331334.

Subbaiah, B. V and Asija, G. L. 1956. A rapid procedure for estimation of available nitrogen in soil. Current Science. 25: 259260.

Syed, T.H., Ganai, M.R., Tahir Ali and Mir, A.H. 2006. Effect of nitrogen and sulphur fertilization on yield and nutrient uptake by sunflower. Journal of the Indian Society of Soil Science. 54(3): 375-376.

USDA National Nutrient Database for Standard Reference. Release 25. 2014.

Walkley, A and Black, C. A. 1934. Estimation of organic carbon by chromic acid titration method.Soil Science.37: 29-38.

White, P.J., Brown, H.C., Marshall, B and Broadley, M.R. 2007. Extraordinary high leaf selenium to sulphur ratios defines Seaccumulator plants. Annals of Botany. 100: 111-118.

\section{How to cite this article:}

Jessie Rebecca, A., P. Surendra Babu and Chandini Patnaik, M. 2018. Effect of Sulphur and Selenium on Yield, Selenium Content and Antioxidant Properties in Sunflower (Helianthus annuus L.). Int.J.Curr.Microbiol.App.Sci. 7(04): 283-289. doi: https://doi.org/10.20546/ijcmas.2018.704.032 